\title{
NUMERICAL MODELING OF GROUNDWATER FLOW CLOSE TO DRINKING WATER RESOURCES DURING FLOOD EVENTS
}

\author{
${ }^{1}$ Tomáš ANDRÁSSY, ${ }^{2}$ Dana BAROKOVÁ \\ Department of Hydraulic Engineering, Faculty of Civil Engineering, \\ Slovak University of Technology in Bratislava, Radlinského 11, 81368 Bratislava, Slovakia \\ e-mail: ${ }^{1}$ tomas.andrassy@stuba.sk, ${ }^{2}$ dana.barokova@stuba.sk
}

Received 20 January 2015; accepted 19 June 2015

\begin{abstract}
When a flood wave passes along the River Danube, the groundwater level rises, hence property is directly threatened and, in particular, the groundwater resources for the water supply located near the affected rivers increase. As the water is polluted during the flood, a solution to this problem is more than necessary. The specific area for this problem - Sihot' Island, was chosen as one of the most significant areas for groundwater supply in Bratislava. This island is flooded repeatedly every year with several floods. Therefore, it is more than necessary to analyze how the groundwater level reacts to the increased water level in the Danube.
\end{abstract}

Keywords: Groundwater flow, Flood situation, TRIWACO code, Modeling, Sihot' island

\section{Introduction}

When a flood wave passes along the River Danube, the groundwater level rises, hence property is directly threatened. This applies, in particular, to groundwater resources located close to the affected rivers. A solution to this problem is more than necessary since during the flood period the water in the Danube is polluted. The specific area of this problem - Sihot' Island in Bratislava, Slovakia - was chosen as one of the most significant areas for water supply in Bratislava. This island is flooded repeatedly almost every year with several floods. Therefore, it is more than necessary to analyze the reaction of the groundwater level to the increased water level in the Danube. Geological, hydrogeological, hydrological and other specific data from that region were used as the input data for the research. The groundwater model was set up, calibrated and verified on the basis of the input data. Subsequently, it could be used for the 
prognosis of groundwater level changes during the flood period as well as for determination of the pollution of groundwater sources. Output from the model will be used for improving the operational rules for groundwater sources during the flood period. The research results will help understanding of the groundwater flow during floods.

\section{Numerical modeling}

Numerical modeling plays an important role in water management. One possibility for groundwater flow modeling is the application of a numerical model, based on mathematical principles [1], [2]. Groundwater flow can be comprehended by using a numerical model. The adequacy of a numerical model is limited by the availability of the necessary input data (hydrogeological conditions, hydrological conditions, etc.), on one hand, and by the characteristics of the applied numerical model (simplified mathematical calculations, finite number of nodes in the numerical model, etc.) on the other. The groundwater model is basically the projection of flow in a porous environment, which hydrogeologists use for prognosis as in [3]. The TRIWACO program package was developed by the Royal Haskoning consortium [4]. TRIWACO is a software system for quasi-3D simulations of groundwater flow based on the finite element method. This program is more or less designed for the solution of groundwater flows in a horizontal plane. The model can be used to model the groundwater flow in a number of permeable layers - aquifers - divided by semi-permeable layers.

\section{Area of interest - Sihot' Island}

The drinking water resource for the City of Bratislava on Sihot' Island is an important hydrological area, hence evaluation of the flood impact on the groundwater level in this area appears to be relevant and useful.

\subsection{Sihot' Island groundwater source}

Sihot' Island is an island in the Danube, which is located in the River Danube at river kilometer 1,872-1,877 (Fig. 1). It has an oblong shape with a maximum length of $3.7 \mathrm{~km}$ and with a maximum width of about $1.0 \mathrm{~km}$. The area of Sihot' Island is $222 \mathrm{ha}$ $\left(2.22 \mathrm{~km}^{2}\right)$. This site is located $5 \mathrm{~km}$ upstream from the periphery of the City of Bratislava on the Danube. At present, there are 12 wide-diameter wells with a diameter from $2,830 \mathrm{~mm}$ to $4,000 \mathrm{~mm}$, one Raney system wide-diameter well with a diameter of $5,000 \mathrm{~mm}$ and 32 drilled wells with diameters of $800 \mathrm{~mm}$ and 1,000 $\mathrm{mm}$. The collecting well of the CS3 pumping station is another wide-diameter well. Water from the wells is pumped by deep-well pumps or automatically using siphons. The Sihot' groundwater source supplies the western part of Bratislava and part of the old town with drinking water. The surface altitude of Sihot' Island is from $135.80 \mathrm{~m}$ a. s. 1. to $139.00 \mathrm{~m}$ a. s. 1 . The island is flooded if the water-level in the River Danube - Bratislava gauging station is higher than $570 \mathrm{~cm} \mathrm{[5].}$ 


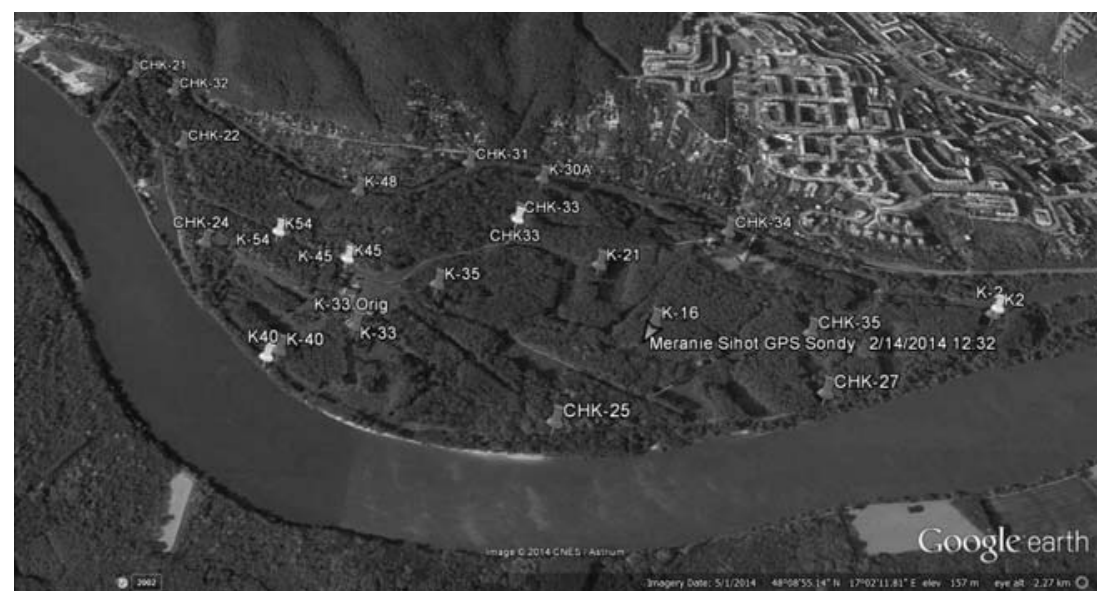

Fig. 1. Localization of wells and routes for measurements

\subsection{Monitoring well network and data collection}

The data for the model were collected manually due to the old and dysfunctional monitoring system in place on Sihot' Island. Twenty wells were chosen for the whole area of the island. The data were collected under different water level conditions in the Danube and they will be used for further simulations.

The objects for groundwater level monitoring, shown in Fig. 1, were chosen to cover the whole area of interest and thus create an ideal network for modeling. The objects were selected based on consultations with the Bratislava Water Company (BWC). Data monitoring and recording was planned for once or twice per week, always in accordance with changes in the River Danube. The monitoring sought to determine the groundwater level behavior for specific water levels in the Danube and was expected to measure the GroundWater Level (GWL) [6], [7] for different water levels in the Danube [5] in the range from low (winter) to high (summer) flow rates.

\section{Simulations}

After collecting the data, modeling of the groundwater flow on Sihot' Island was introduced. Simulations were performed using the TRIWACO groundwater model [4]. The procedure was carried out in these phases:

1. Design of grid on basis of underlying data;

2. Set-up of initialization file;

3. Set-up of calibration file;

4. Calibration;

5. Verifications;

6. Min. and max. discharge simulations;

7. River Danube flood levels simulation;

8. Results. 


\subsection{Grid design}

A broader area of interest around Sihot' Island was chosen as the border of the modeling area. This area was selected in order to be able to take into consideration the specific inflow of rainfall into the area as well as the position of the gauging stations on the River Danube - in Devin and in the center of Bratislava. The proposed boundaries of the model area are shown in Fig. 2.

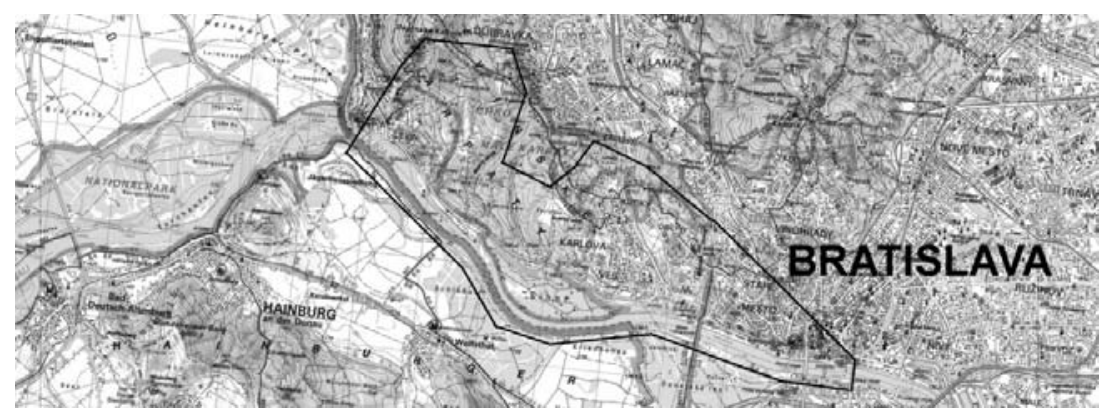

Fig. 2. Boundaries for simulations (BND)

On the northern side the model area is demarcated by the Small Carpathians, which define the catchment area on the north of the area of interest. To the east the model area is demarcated by the old bridge in Bratislava. The south side of the area is demarcated by the River Danube. On the west and northwestern sides the area is demarcated by the Danube and Morava Rivers. Polygons with different densities of elements (100 m and $50 \mathrm{~m}$ ) were subsequently created to establish the finite element mesh (Fig. 3).

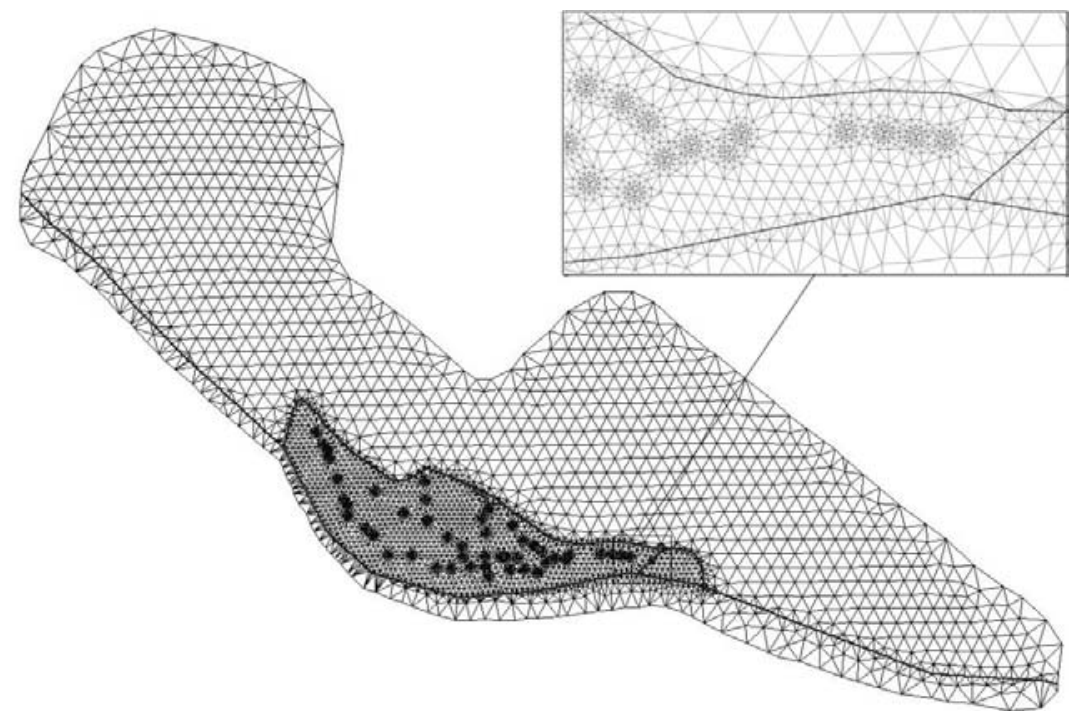

Fig. 3. Finite element mesh with details around wells 
The Danube and Morava were defined, as well as the by-pass arm alongside Sihot' Island. The monitoring and pumping wells were defined on Sihot' Island using the geodetic coordination system. In order to achieve more precise calculations, the network was rendered denser in the surroundings of these points by supporting circles, thus the design of the area was completed and a finite element mesh was generated in the TRIWACO modeling system, which was used for subsequent modeling.

\subsection{Boundary conditions}

Boundary Conditions (BC) were entered as follows: to the west and east the Cauchy BC - the water level in the Danube was introduced. To the north and south, the Neumann BC - zero flow into the area was used. The area of interest is located in the middle of the modeled area - distant from the boundaries - to mitigate the influence of $\mathrm{BC}$ when solving the GWL regime.

\subsection{Parameterization of filtration area}

Based on the description of the area in chapter 3, the following parameters were determined: the width of the Danube varies from $350 \mathrm{~m}$ to $270 \mathrm{~m}$; also the width of the Karloveské rameno segment ranges from $30 \mathrm{~m}$ to $80 \mathrm{~m}$. The width of the river corresponds to the River Width (RW1) parameter shown in Fig. 4.

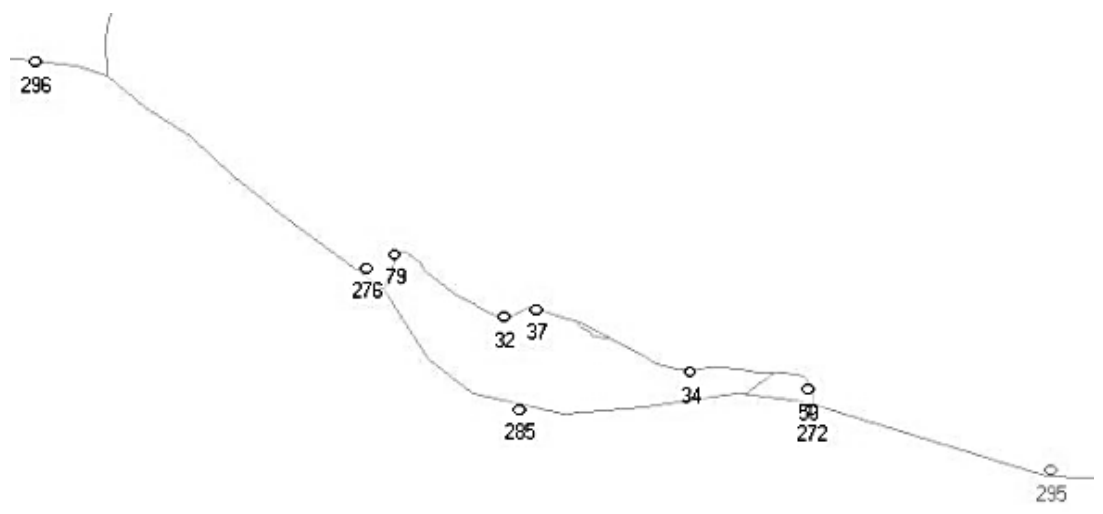

Fig. 4. River width (RW1) parameter settings (m)

The River Danube water level in the model area was monitored at two gauging stations - at Devín located about $2 \mathrm{~km}$ upstream from Sihot' Island and at the Bratislava gauging station located about $2 \mathrm{~km}$ downstream from Sihot' Island. Their positions are shown in Fig. 5.

These values were measured and recorded during the field measurements together with the values of GWL in wells. The water level in the river corresponds to the River Head (HR1) parameter. It was also necessary to specify the value of drainage resistance (CD1) and infiltration resistance (CI1) [8]. Based on previous studies [9], [10] the value of drainage resistance (CD1) of 0.5 day was used and the value of CI1 - infiltration resistance (CI1), was set as twice the value of drainage resistance. For simulations, it 
was necessary to enter the top and bottom boundaries of the aquifer and the hydraulic conductivity. These values were recorded in files of the top of aquifer RL1, bottom of aquifer TH1 and hydraulic conductivity PX1.

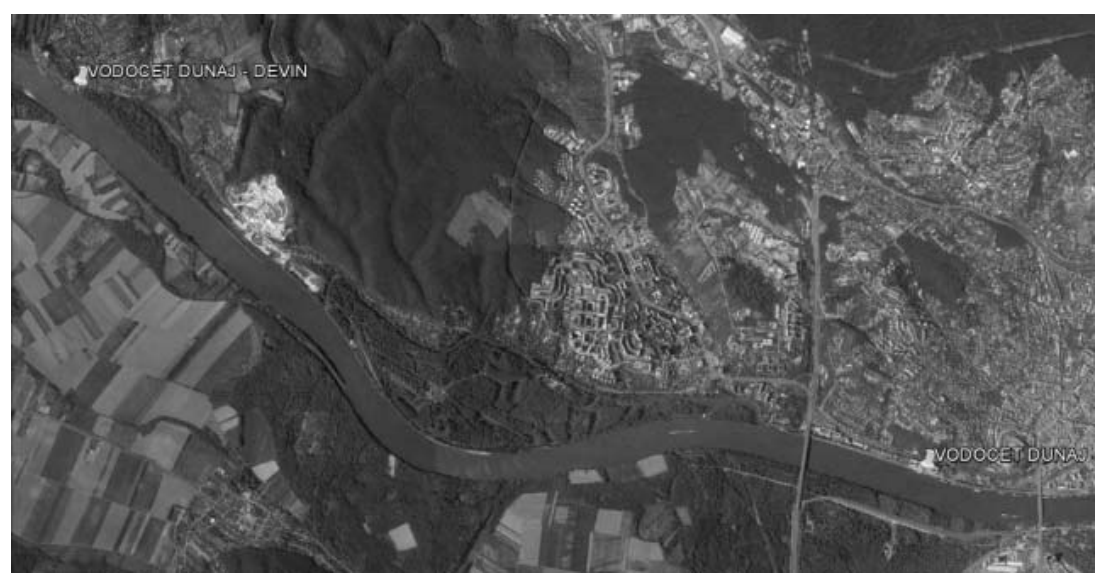

Fig. 5. Location of gauging stations

When entering the effective precipitation RP1, average monthly recharge of 0.0006 m. $\mathrm{d}^{-1}$ from the Bratislava - Koliba station was used [5].

Due to the possibility of the Karloveské rameno drying up, it was necessary to take the activity of this segment of the Danube into account. The first calculation (based on the water in the river segment), the value was set as a constant RA1, i.e. 1 for all river segments of the Danube. The value of PX1 was determined according to reports from pumping tests [11] as a constant $445 \mathrm{~m} \cdot \mathrm{day}^{-1}$. For the calculations, it was also necessary to set up the coordinates of individual wells on Sihot' Island. The location of the wells (Fig. O) and the discharge were recorded in the source discharge in the aquifer parameter, SQ1.

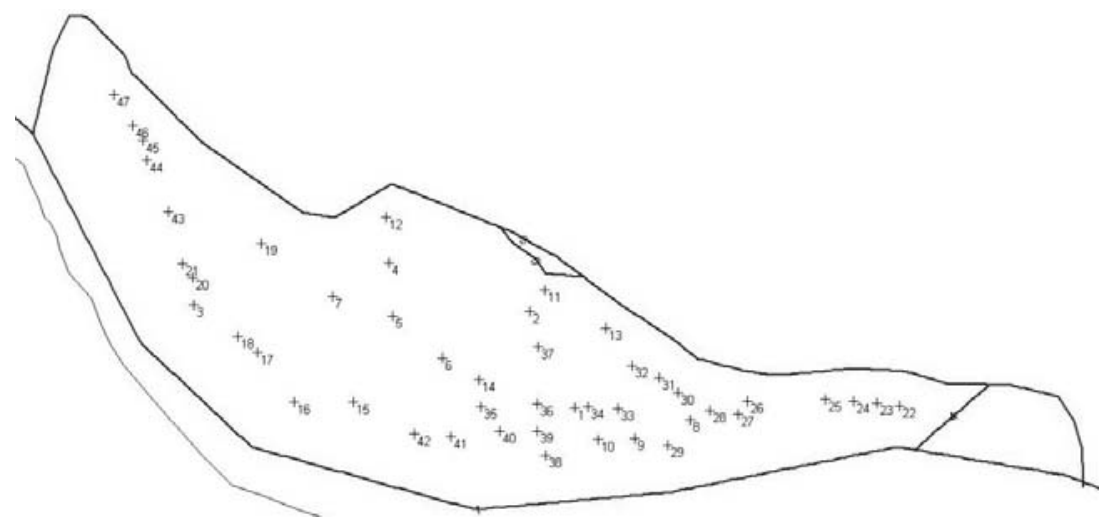

Fig. 6. Location of wells at Sihot' Island 
In order to determine GWL on the boundaries of the area of interest, parameter BH1 was set up for the initial calculations as the level of the Danube and, since the given area is highly permeable (in the order of $10^{-3} \mathrm{~m} \cdot \mathrm{s}^{-1}$ ), this value was assumed to pertain for the whole area.

\subsection{Setting up the calculation and calibration}

In the first series of calculations, all the parameters were set as in the initialization file. The input file was generated with these settings and then the calculation was run. The results of the piezometric head in aquifer1 (PHI1) are shown in Fig. 7. The calibration values from the measurements were used. The results are shown in the table in Fig. 8; as only slight differences appeared between the calculated and measured values of GWL, the model was regarded as properly configured and deemed suitable for further simulations.

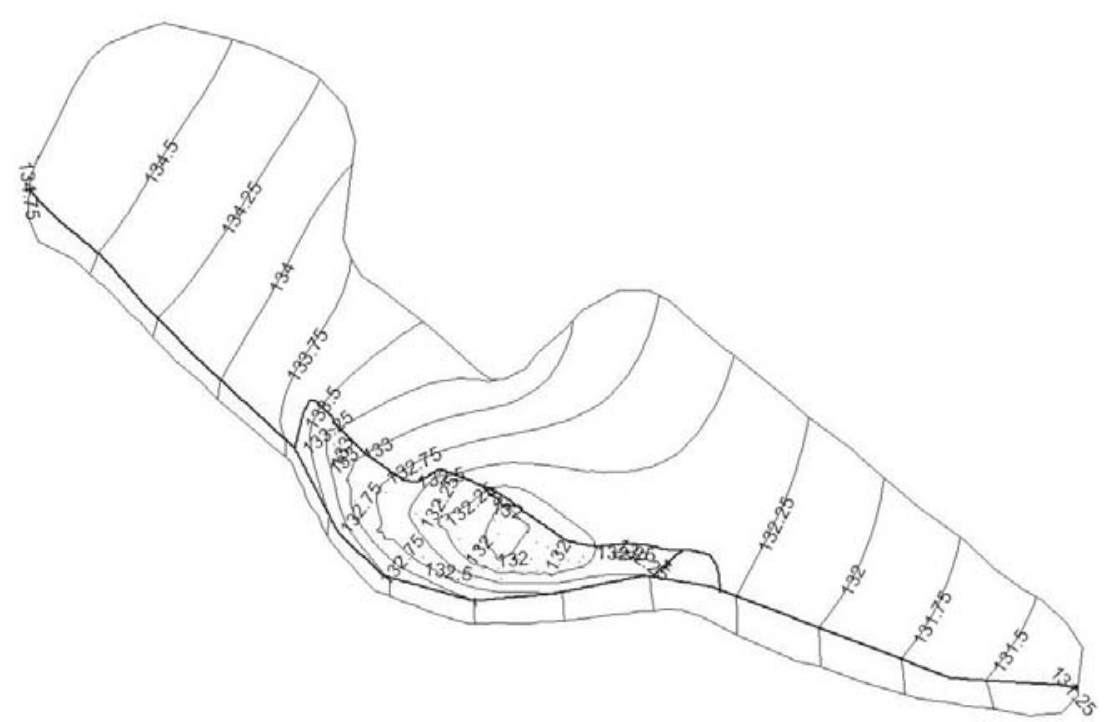

Fig. 7. Groundwater level contour map (m a. s. 1.), River Danube level - $134.3 \mathrm{~m}$ a.s.1. at the Devin gauging station and average discharge on Sihot' Island

\subsection{Simulation of GWL for minimum and maximum discharges}

After the calibration process was completed, simulation for minimum discharge from 41 active wells was carried out, (Table I) i.e. $4641 . \mathrm{s}^{-1}$ and at maximum discharge withdrawn by pumping $8681 . \mathrm{s}^{-1}$ at normal level in the River Danube (Fig. 8).

The simulation of the GWL was performed for all three Degrees of Flood Stages (DFS) on the Danube in June 2013. Water-level and flood conditions data are shown in Table II. 


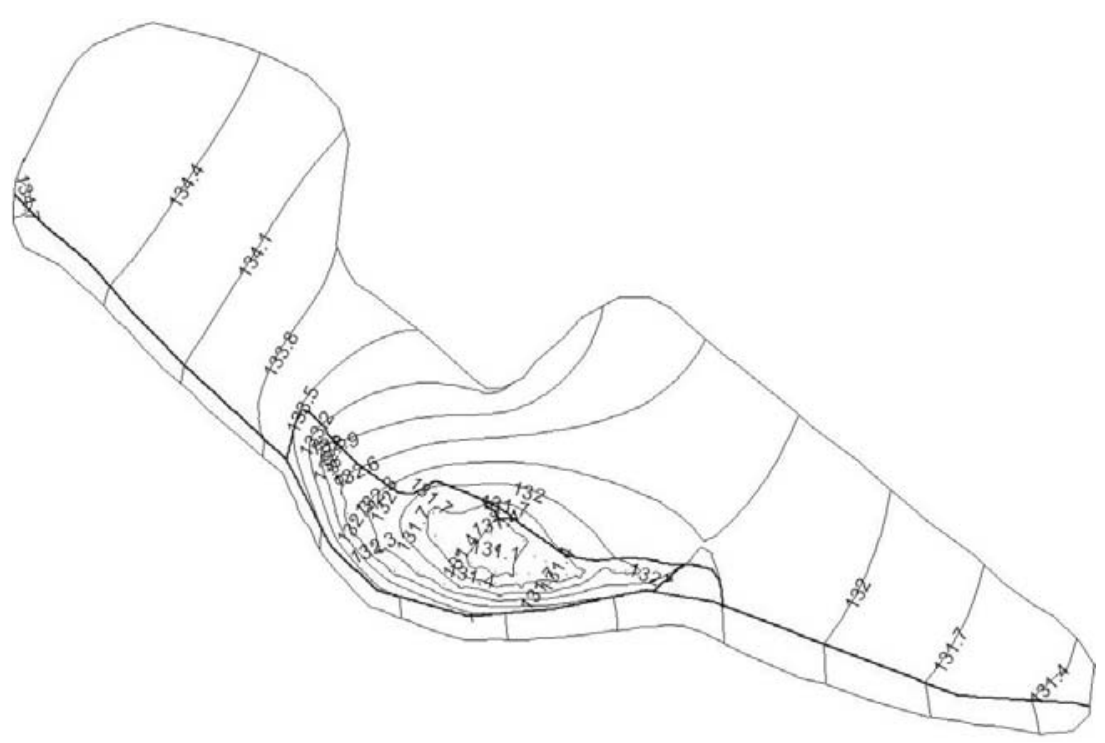

Fig. 8. GWL (m a. s. 1.) at maximum discharge from 41 wells

\section{Table I}

Differences between calculated and measured piezometric head values at checkpoints after model calibration

\begin{tabular}{|c|c|c|c|}
\hline NAME & CALCULATED & MEASURED & DIFFERENCE \\
\hline 2 & 132.031 & 132.343 & -0.312 \\
3 & 132.113 & 132.006 & 0.107 \\
4 & 132.218 & 131.604 & 0.614 \\
5 & 132.402 & 132.144 & 0.258 \\
6 & 132.757 & 132.612 & 0.145 \\
7 & 133.046 & 132.847 & 0.199 \\
8 & 133.015 & 132.573 & 0.442 \\
9 & 133.025 & 132.621 & 0.404 \\
10 & 133.321 & 132.861 & 0.460 \\
11 & 133.554 & 133.148 & 0.406 \\
12 & 132.762 & 132.325 & 0.437 \\
13 & 132.649 & 132.166 & 0.483 \\
14 & 132.624 & 132.229 & 0.395 \\
15 & 132.718 & 132.435 & 0.284 \\
16 & 132.439 & 132.092 & 0.347 \\
17 & 132.292 & 132.058 & 0.234 \\
18 & 132.511 & 132.132 & 0.379 \\
19 & 132.38 & 132.112 & 0.268 \\
20 & 132.099 & 131.517 & 0.582 \\
\hline
\end{tabular}

Pollack Periodica 11, 2016, 1 
Table II

River Danube water-levels during flood in June 2013

\begin{tabular}{|c|c|c|c|c|c|}
\hline \multirow{2}{*}{\multicolumn{2}{|c|}{$\begin{array}{c}\text { River: } \\
\text { Gauging station: }\end{array}$}} & \multicolumn{4}{|c|}{ DANUBE } \\
\hline & & \multicolumn{2}{|c|}{ Bratislava } & \multicolumn{2}{|c|}{ Devín } \\
\hline \multicolumn{2}{|c|}{ Zero of gauge: } & \multirow{2}{*}{\multicolumn{2}{|c|}{$\frac{128.43 \mathrm{~m} \text { a. s. } 1 .}{\text { water level }}$}} & \multirow{2}{*}{\multicolumn{2}{|c|}{$\frac{132.87 \mathrm{~m} \text { a. s. } 1 .}{\text { water level }}$}} \\
\hline \multirow{2}{*}{ Datum } & \multirow{2}{*}{$\begin{array}{c}\text { Degree of flood } \\
\text { stage }\end{array}$} & & & & \\
\hline & & $\mathrm{cm}$ & m a.s. 1. & $\mathrm{~cm}$ & m a.s. 1. \\
\hline 3.6 .2013 & 1. & 708 & 135.51 & 670 & 139.57 \\
\hline 4.6.2013 & 2. & 820 & 136.63 & 800 & 140.87 \\
\hline 5.6 .2013 & 3. & 940 & 137.83 & 920 & 142.07 \\
\hline
\end{tabular}

\subsection{Simulations of groundwater level at different flood situations}

On the cross section A-A' (Fig. 9) shown in Fig. 10, the GWL at the $1^{\text {st }}$ DFS is roughly one meter below the terrain - the thinner line under almost the entire area. At the $2^{\text {nd }}$ DFS, the GWL is almost linked to the surface level of the River Danube, and in some places the island is flooded and the GW becomes joined with the surface water. At the $3^{\text {rd }}$ DFS, the GWL is completely joined with the level of the river and the whole island is completely flooded, as shown in Fig. 11.

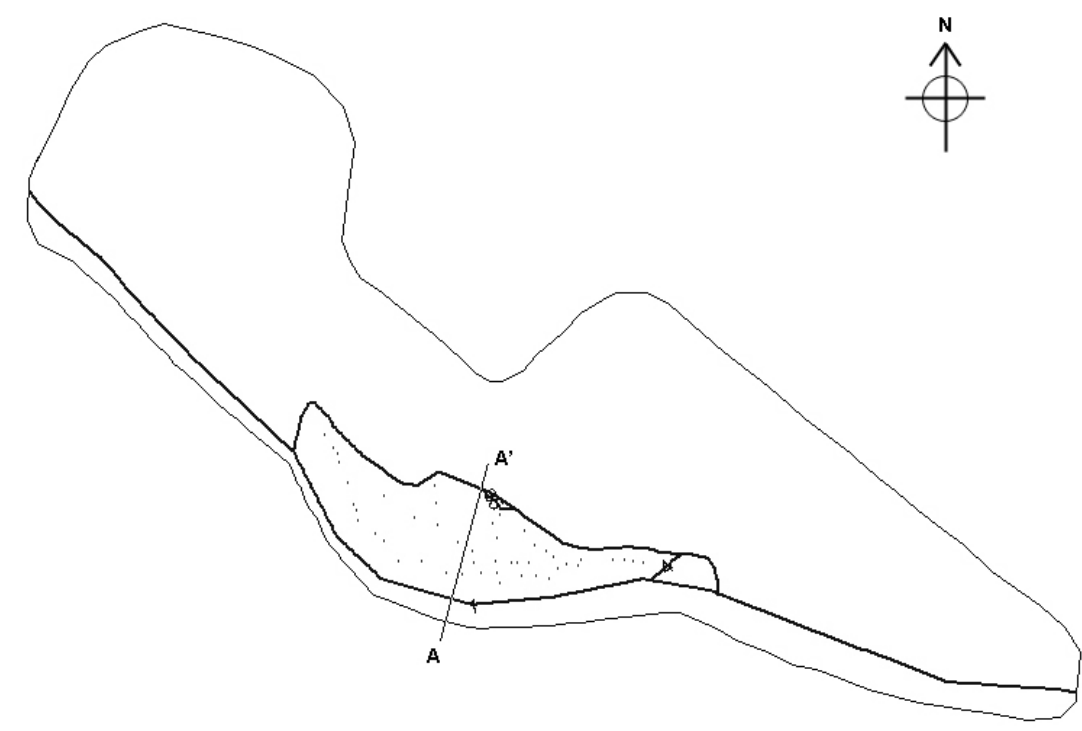

Fig. 9. Position of A-A' cross-section (NW-SE) across Sihot' Island

\section{Conclusion}

Climate change is likely to affect groundwater due to changes in precipitation, evapotranspiration, etc. With more moisture in the atmosphere, rainfall and snowfall 
events tend to be more intense, increasing the potential for a greater likelihood of flooding as well as more droughts. The problem of flooding occurs almost every year, which gives rise to threats to the groundwater resources in Sihot' Island on the River Danube in Bratislava. Accordingly, a groundwater source area of interest was created in the TRIWACO modeling system on the basis of geological, hydrogeological and topographic data.

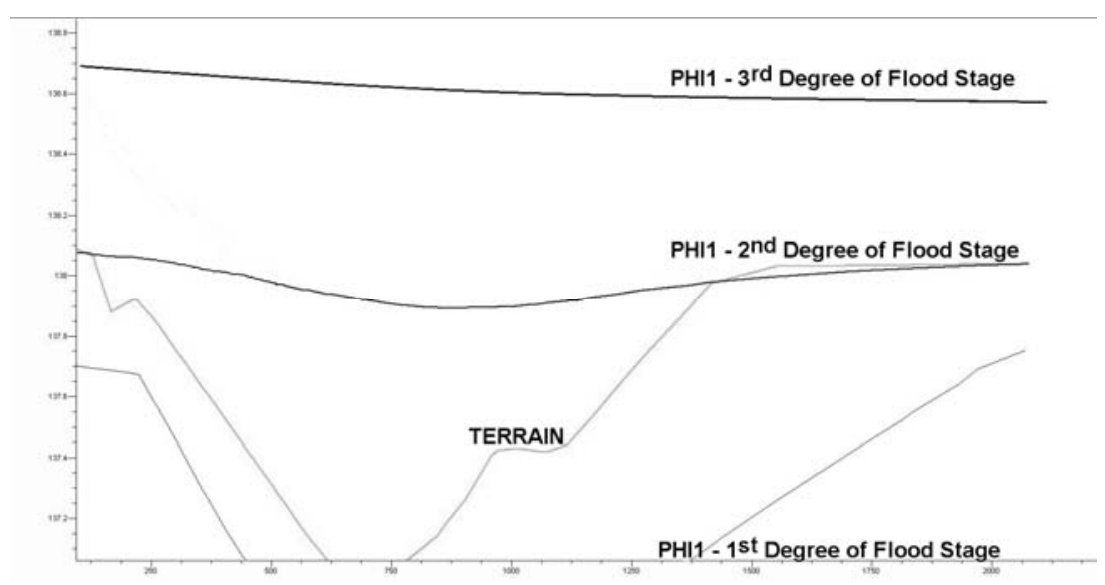

Fig. 10. Piezometric head (m a. s. 1.) for $1^{\text {st }}, 2^{\text {nd }}$ and $3^{\text {rd }}$ DFS in A-A' cross-section

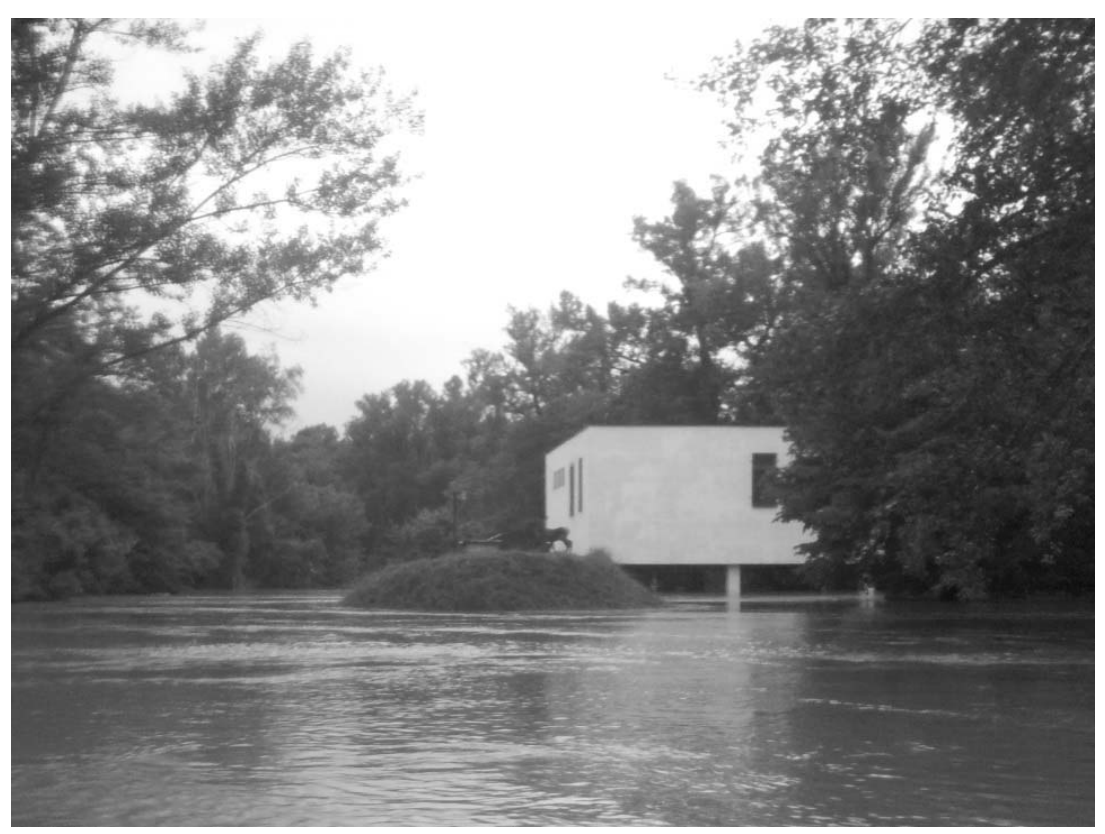

Fig. 11. Actual water level between $2^{\text {nd }}$ and $3^{\text {rd }}$ DFS at Sihot' Island 
It was subsequently set up, calibrated and verified as a proper model of the area of interest. The model was verified on the basis of data obtained by field measurements. Consequently, GWLs were calculated for the average and maximum discharges and it was confirmed that, at maximum discharge, a significantly greater depression (depression cone) was generated in the eastern part of the island with the largest number of active wells. Simulations were performed for different degrees of flood stages. From the $2^{\text {nd }}$ DFS, the island was observed to gradually become flooded and a groundwater level and free surface level changeover occurred. There is a need to adapt the operation of water resources (increased drinking water quality control or increased dosage of disinfectants). For future applications, a multi-layered model will be created; the map of GWL, groundwater flow direction or velocity will be produced by means of simulation. The results are to be used for possible adjustment of the pumping plan for Sihot' Island.

\section{Acknowledgements}

This work was undertaken as part of a project supported by the VEGA Grant Agency under Contract No. 1/1011/12.

\section{References}

[1] Říha J., Stara V., Jandora J., Maděřič R., Prax P., Ryl T., Uhmanová H. Mathematical modeling of the hydrodynamic and dispersion phenomena, (in Czech) Brno, Vysoké učení tehnickév Brně, 1997.

[2] Kováŕík K. Numerical models in groundwater pollution, Berlin, Heidelberg, Springer Verlag, 2000.

[3] Benetin J., Šoltész A. Method of the prognosis of the soil-water regime in the river zone (in Slovak) Journal of Hydrology and Hydromechanics, Vol. 38, No. 6, 1990, pp. 577-596.

[4] Royal Haskoning, Triwaco groundwater modeling software, Triwaco User's Manual, Royal Haskoning Division Water, Haskoning Netherlands BV, Rotterdam, Netherlands, 2004.

[5] Blaškovičová L., Podolinská, J, Liová M., Fabišíková M., Rischaneková M., Danáčová J., Marikovičová J. Hydrological Yearbook of Surface Waters 2005, Slovak Hydrometeorological Institute, Bratislava, 2006.

[6] Čaučík P., Leitmann Š., Sopková M., Možiešiková K., Molnár L., Bodácz B., Lehotová D., Mada I., Kurejová-Stojková M. Water balance of the SR, Quantitative water balance of groundwater for the year 2013, (in Slovak) Slovak Hydrometeorological Institute, Bratislava, 2014

[7] Kullman E., Gavurník J., Molnár L., Pal’ušová Z., Lehotová D., Bodácz B., StojkováKurejová M., Saglenová A., Palková M. Hydrological Yearbook - part groundwater, 2013, (in Slovak) Slovak Hydrometeorological Institute, Bratislava, 2014.

[8] Zaadnoordijk W. J. Simulating piecewise-linear surface water and ground water interactions with MODFLOW, Ground Water, Vol. 47, No. 5, 2009, pp. 723-726.

[9] Pelikán P., Šlezingr M. Methodology for the establishment of physical and geometric properties of a drainage basin, Acta Universitatis Agriculturae et Silviculturae Mendelianae Brunensis, Vol. 59 No. 6, 2011, pp. 265-270. 
[10] Velísková Y., Koczka Bara M., Dulovičová R., Schügerl R. Influence of surface water level fluctuation and riverbed sediment deposits on groundwater regime, Journal of Hydrology and Hydromechanics, Vol. 62, No. 3, 2014, pp. 177-185.

[11] Dinda F. First water source Bratislava Sihot', (in Slovak) Engineering Geological Hydrological Project, Žilina, 1966. 